University of Nebraska - Lincoln

DigitalCommons@University of Nebraska - Lincoln

Faculty Publications, Department of Psychology

Psychology, Department of

2004

\title{
Paying for the Crimes of Their Children: Public Support of Parental Responsibility
}

\author{
Eve M. Brank \\ University of Nebraska-Lincoln, ebrank2@unl.edu \\ Victoria Weisz \\ University of Nebraska-Lincoln, vweisz1@unl.edu
}

Follow this and additional works at: https://digitalcommons.unl.edu/psychfacpub

Part of the Psychiatry and Psychology Commons

Brank, Eve M. and Weisz, Victoria, "Paying for the Crimes of Their Children: Public Support of Parental Responsibility" (2004). Faculty Publications, Department of Psychology. 551.

https://digitalcommons.unl.edu/psychfacpub/551

This Article is brought to you for free and open access by the Psychology, Department of at DigitalCommons@University of Nebraska - Lincoln. It has been accepted for inclusion in Faculty Publications, Department of Psychology by an authorized administrator of DigitalCommons@University of Nebraska - Lincoln. 


\title{
Paying for the Crimes of Their Children: Public Support of Parental Responsibility
}

\author{
Eve M. Brank ${ }^{\mathrm{a}}$ and Victoria Weisz ${ }^{\mathrm{b}}$
}

aDepartment of Criminology, Law, and Society, University of Florida, Gainesville, Florida, USA; affiliation 2009-: Department of Psychology, University of Nebraska-Lincoln, Lincoln, Nebraska, USA; ebrank2@unl.edu (corresponding author)

${ }^{b}$ Center on Children, Families, and the Law, University of Nebraska-Lincoln, Lincoln, Nebraska, USA; vweisz1@unl.edu

\begin{abstract}
Parental responsibility laws, varying greatly within and among the states, appeared as one answer to the questions surrounding juvenile crime. Although these laws would seem to garner great public support under the new punitive attitude toward juveniles, no recent empirical studies were conducted on this topic. The current research examined public support of parental responsibility for crimes children commit. Contrary to expectations, public support was found to be relatively low. The public did place some responsibility on the parents when a juvenile crime occurred; however, agreement with blaming and punishing the parents was low. Political ideology and educational status served as possible predictors of support. Overall, however, demographic variables proved not predictive in determining who would support these measures.
\end{abstract}

\section{Introduction}

Public opinion matters in the United States (Kingdon, 1995). Public support often motivates the imposition of new laws and the active enforcement of current laws (Warr, Meier, \& Erickson, 1983). For instance, the policy agendas that determine the apportionment of funds were shown to be affected by public opinion (Hollin \& Howells, 1987; Tyler, 1990). For these reasons and others, public support and opinion were studied related to a number of criminal justice topics such as the death penalty (Ellsworth \& Gross, 1994; Radelet \& Borg, 2000), domestic drug control (Lock, Timberlake, \& Rasinski, 2002), juvenile crime (Bouley \& Wells, 2001), and racial profiling (Weitzer \& Tuch, 2002). The goals of the current research were to examine the public opinion toward placing responsibility on parents, blaming of parents, and punishing parents for the crime their children commit.

\section{Parental Responsibility}

Generally, a person has no legal "duty to act" and is not responsible for the actions of others. Under common law, parents are not responsi- ble for the torts or criminal actions of their children. The exception to this rule is the "negligent supervision" concept when parents are negligent in some way and therefore become liable. Generally, the tort of negligent supervision creates liability if the parents entrust their child with a dangerous instrument or if the parents are aware of their child's vicious propensities (Hanson, 1989a, 1989b; Levine, 1984). Basic tort principles apply so that the plaintiff is required to prove the existence of a duty, breach of that duty, proximate cause, and damages. These requirements make recovery possible in only a few narrow situations (Hanson, 1989a). The unlikely success of these cases, the equally unlikely recovery of total losses from a child, and the desire to get tough on juvenile crime have led to more broadly defined parental responsibility statutes.

The three forms of statutorily defined parental responsibility laws expand the common law by creating a duty to act and making parents responsible, in addition to the juvenile's own responsibility, for their child's actions. These three forms include holding parents: (1) civilly liable for property damage or personal injury, (2) 
criminally liable because they contributed to the delinquency of their child, and (3) legally "responsible" by requiring parental involvement with the child's criminal sanctions. In the first form of parental responsibility laws, parents are civilly liable for the actions of their children. A plaintiff may bring a case against the parents of a child who injures the plaintiff or damages the plaintiff's property. In the second type, a legal guardian or another adult is made criminally responsible for encouraging delinquency in a minor. The third type represents legislative efforts to involve parents in the juvenile court processes and beyond. These laws often order the parents to pay for the court costs, pay restitution, pay treatment costs, and participate in the juvenile's case (Brank, Kucera, \& Hays, 2003; Davies \& Davidson, 2001). It should also be noted that except for the parental civil liability laws, these statutes as a whole do not release the juvenile from their own responsibilities and punishments, but make the parents an additional party. Virtually no public support research existed on parental responsibility laws. The intention of the current study was to address whether the public supported the underlying concepts of parental responsibility laws. General support for parental responsibility, blaming, and punishing was examined. In addition, demographic characteristics were examined as possible predictors of support.

\section{Juvenile Justice Setting}

To put parental responsibility laws in perspective, it was necessary to first review the current juvenile justice system generally. Western cultures had long recognized the notion of having a different and distinct system for children. Early English Common Law recognized that children should not be subject to the same punishments as adults (Bartollas \& Miller, 1994). More than one hundred years ago, the United States established its first juvenile court system in Chicago (Gardner, 1997). The purpose of the juvenile system was to rehabilitate troubled youth by offering individualized and non-punitive dispositions according to the minor's needs (Gardner). As a trade off for the rehabilitative objective, the juvenile system afforded fewer constitutional protections than the adult criminal system (Gardner).

In recent decades, the distinction between the juvenile and adult systems began to erode (Hirschi \& Gottfredson, 1993). The juvenile system was developed around the parens patriae theory. Any contact a juvenile would have with the system was to promote the juvenile's welfare; therefore, states reasoned that procedural protections were unnecessary (Gardner, 1997). The Supreme Court was skeptical of the parens patriae excuse for depriving juveniles of procedural protections. In a series of cases beginning in 1966, the Supreme Court gave juveniles the same Constitutional protections, except jury trials, that were given to adults Breed v. Jones (1975); In re Gault (1967); In re Winship (1970); Kent v. United States (1966); McKeiver v. Pennsylvania (1971).

Even with the diminishing distinctions, the juvenile system remained a separate entity from the adult criminal system (Gardner, 1997). Three movements were taking place that might lead to even less of a difference between the two systems. The first was a general movement away from rehabilitation and toward a more punitive system (Podkopacz \& Feld, 2001). For example, statutory changes incorporated punishment and accountability into Washington's juvenile code (Intent-Purpose, 1997). The second movement involved the more drastic call to abolish the juvenile justice system completely (Ainsworth, 1991). The result would have every juvenile automatically tried as an adult. The third movement was represented by the rise in juvenile transfers into the adult criminal system (Bishop \& Frazier, 1991; Quinn, 2002; White, Frazier, \& Lanza-Kaduce, 1999). Although not a complete abolishment of the juvenile system, many states were increasing the list of crimes and decreasing the minimum age that made a juvenile eligible for transfer (Heilbrun, Leheny, Thomas, \& Honeycutt, 1997).

These three movements demonstrated the political agenda to "get tough on juvenile crime," as well as a political movement that reflected general public attitudes. For example, a 2000 Gallup Organization public opinion poll revealed a public desire for less differentiation between the adult and juvenile systems. Sixty-five percent of the respondents indicated that the justice system should treat juveniles between the ages of fourteen and seventeen whocommitted violentcrimes the same as adults (Gallup Poll Surveys, 2000). The public's "get tough on juvenile crime" attitude may stem from their erroneous beliefs about juvenile crime. The Justice Policy Institute reported that Americans thought juveniles were responsible for $43 \%$ of the homicides that occurred in this country. In fact, juveniles were responsible for approximately $9 \%$ 
of the homicides (Schiraldi \& Ziedenberg, 2001). Nearly two-thirds of Americans thought juvenile crime was on the increase, but a $58 \%$ decline in juvenile homicides occurred since 1994 (Schiraldi \& Ziedenberg). In fact, juvenile violent crime such as murder, forcible rape, robbery, and aggravated assault, was consistently decreasing since 1994 (Snyder, 2000). The juvenile murder rate alone fell 68\% between 1993 and 1999 to the lowest level since the 1960s (Snyder). The violent crime rate that peaked in the mid-1990s appeared to be waning (Snyder). Like violent crime, property offenses committed by juveniles were also decreasing. Property offense arrest rates dropped almost 30\% between 1994 and 1999 (Snyder). Thus, the data did not confirm that juvenile crime was out of control; in fact, the current rate of serious juvenile offending was comparable to that of the late 1960s and early 1970s (Bilchik, 2000). Teenagers are quite different, however, than they once were. More than half of all teenagers are now growing up without a parent at home during the day (Hine, 1999, p. 281). As a result, youth have looser ties to the home, and in turn, may be open to greater influences by their peers (Hine).

To summarize, the entire juvenile justice system saw marked changes in recent years. The Supreme Court granted procedural protections to juveniles (Breed v. Jones, 1975; In re Gault, 1967; In reWinship, 1970; Kent v. United States, 1966) while a movement continues toward a more punitive, rather than rehabilitative system (Feld, 1991). Juveniles are being tried as adults at younger ages and for a wider variety of crimes (Heilbrun et al., 1997). Most juvenile crime is decreasing, while the public believes the opposite (Snyder, 2000). Parental responsibility is one piece of this juvenile justice puzzle that has developed as a solution to the public outcry against juvenile delinquency while still maintaining a semblance of rehabilitation (Samborn, 1996). Parental responsibility laws are not part of the movement to make the juvenile system more like the adult system. Rather, they represent an attitude that juveniles are not mature enough to be held solely responsible for their actions; therefore, their parents must also be involved (DiFonzo, 2001).

Public support for parental responsibility laws A 1957 survey of 323 adults found that 88\% thought that parents were a main cause of juvenile delinquency (Kenny \& Kenny, 1961). A slight majority, $54 \%$, thought parents should be held responsible for their child's delinquen- cy (Kenny \& Kenny, 1961). Thirty-five percent said that the parents should be held "partially" responsible. A 1996 New York Times/CBS News poll reported that $72 \%$ of the respondents said that parents should be held responsible for their children's crimes (Applebome, 1996), suggesting a possible increase of support. Certainly, support of parental involvement was evidenced in state statutory requirements. Parents are frequently requested or required to participate in the court hearings, diversion programs, and delinquency treatments (Davies \& Davidson, 2001). Furthermore, the role of family and/ or family socialization was implicated in several criminological theories (see Gottfredson \& Hirschi, 1990; Moffitt, 1993; Patterson, DeBaryshe, \& Ramsey, 1989).

Once it has been determined that people do support a law, the next step is to understand why they support that law. This has been a topic of interest especially in understanding why people want to punish rule breakers (Tyler \& Boeckmann, 1997). Often, complicated factors become relevant in this decision making process. For instance, Reuterman (1978) concluded that demographic factors formed a complex and multidimensional explanation of support for some laws.

In research on attitudes toward sentencing, respondent characteristics generally had small, and sometimes inconsistent effects (Applegate, Cullen, Turner, \& Sundt, 1996). As an example, Blumstein and Cohen (1980) reported greater punitiveness associated with White respondents, older respondents, and those from higher income brackets. In contrast, Tyler and Boeckmann (1997) found that the young and minorities were more punitive. Both sets of researchers found that less punitiveness was associated with higher educational attainment (Blumstein \& Cohen; Tyler \& Boeckmann).

Banks, Maloney, and Willcock (1975) performed a large public opinion study (2,846 participants) concerning the causes of crime. The participants were presented with ten statements and asked which ones they thought were the causes of crime. Seventy percent of the participants indicated that a cause of crime was that parents did not have the authority over their children. Although these researchers found no gender differences in the respondent's opinions, age differences were detected. They found that respondents over fifty years old were more likely than those under fifty years old to indicate that the causes of crime were related to a decline in parental authority. 
Reuterman (1978) also investigated public views of the causes of delinquent behaviors. Although his results indicated that the public favored an explanation that included numerous factors, this research did find that a greater number of females $(36 \%)$ than males $(20 \%)$ viewed lack of parental supervision as a cause of delinquency. No significant differences were found among age groups; however, respondents between the ages of thirty-five and sixty-five tended to blame a lack of parental control for delinquent behavior.

Confirming Reuterman's gender difference finding, Furnham and Henderson (1983) also found that women in their study commonly explained delinquency as resulting from the juvenile's socialization in the home. This survey study was conducted in Britain and included 370 adults. The participants rated on a sevenpoint "importance" scale a list of thirty common explanations for delinquency. The third most important factor based on the mean ratings was the lack of strong parental guidance provided to the juveniles $(\mathrm{M}=2.56$, with lower means indicating more importance). This parental explanation to delinquency was only less important than lack of job opportunities for juveniles $(\mathrm{M}=2.28)$ and living in high areas of delinquency $(\mathrm{M}=2.48)$. Nine of the thirty delinquency explanations yielded significant gender differences, with the women more than men finding explanations that related to the juvenile's socialization in the home and school being more important. Age differences were also explored in this study. For the explanation of delinquency related to youth not having strong parental guidance, age produced a Ushaped relationship $(F=5.43, p<0.001)$. Middle-aged respondents gave this explanation greater importance than did younger and older respondents. Voter affiliation was also compared with the group divided between the Labour and Conservative voters. Conservatives found the explanation of parental guidance significantly more important than the Labour voters $(F=13.35, p<0.001)$.

These studies illustrated that demographic variables influenced public opinion about delinquency; however, it was not known if these same characteristics influenced support for parental responsibility. Blaming and punishing parents shifts a person's punitive focus away from the child and onto the parents. Does that shift alter the demographic effect on public opinion?
To answer this question, the current research examined gender, age, educational level, race, income, and political affiliation in relation to general public support for parental responsibility. In that vein, the first hypothesis was that significantly more respondents would favor parents as responsible rather than peers, schools, or media. In addition, mean agreement ratings would generally support parental blaming and parental punishment with the two being significantly correlated. These predictions were based on the general movement that was taking place in the juvenile justice system. In other words, the push toward a more punitive juvenile system would be reflected in agreement with parental responsibility, blaming, and punishment.

Demographic variables were examined in relation to support of parental responsibility. This was a relatively new area of research; therefore, theories for predictions of support were borrowed from earlier public opinion research related to delinquency. Based on the Reuterman (1978) and Furnham and Henderson (1983) finding that women were more likely than men to view delinquency problems as stemming from the home, it was predicted that women more than men would view parents as responsible. Age was predicted to have a negative linear relationship with agreeing that parents should be blamed and punished. In other words, it was expected that the results would be similar to those of Banks et al. (1975) with older participants agreeing that parents were responsible and should be punished. It was also hypothesized that the current results would be complementary to those of Blumstein and Cohen (1980) and Tyler and Boeckmann (1997) who found that higher educational attainment was associated with less punitiveness. Therefore, the higher the educational attainment of the participants, the less they would believe that parents should be punished. Based on the findings again from Blumstein and Cohen, race and income were predicted to produce differences in agreement. It was expected that minorities and those in the lower income brackets were less likely to believe that parents were responsible and should be punished. In addition, it was hypothesized that the more conservative a person was, the more punitive they would be (Moon, Wright, Cullen, \& Pealer, 2000) which would result in greater agreement that parents were responsible, blameworthy, and deserving of punishment. 
Table 1

Attitudes toward responsibility by race and gender

\begin{tabular}{|c|c|c|c|c|c|c|c|c|c|c|c|}
\hline & \multicolumn{2}{|l|}{ Parents } & & \multicolumn{2}{|l|}{ Peers } & & \multicolumn{2}{|l|}{ Media } & & \multicolumn{2}{|l|}{ School } \\
\hline & Percent & $(N)$ & & Percent & $(N)$ & & Percent & $(N)$ & & Percent & $(N)$ \\
\hline Females & 66.5 & $(310)$ & Females & 22.5 & $(105)$ & Females & 10.7 & (50) & Females & 0.2 & (1) \\
\hline White & 66.8 & $\overline{(272)}$ & White & 22.9 & (93) & White & 10.1 & $\overline{(41)}$ & White & 0.2 & (1) \\
\hline Black & 62.9 & $(22)$ & Black & 22.9 & (8) & Black & 14.3 & (5) & Black & 0.0 & (0) \\
\hline Other & 65.0 & (13) & Other & 20.0 & (4) & Other & 15.0 & (3) & Other & 0.0 & (0) \\
\hline Males & 71.1 & (303) & Males & 20.7 & $(88)$ & Males & 7.5 & (32) & Males & 0.7 & (3) \\
\hline White & 72.0 & $\overline{(260)}$ & White & 19.9 & $(72)$ & White & 7.2 & $(26)$ & White & 0.8 & (3) \\
\hline Black & 58.3 & (14) & Black & 29.2 & (7) & Black & 12.5 & (3) & Black & 0.0 & (0) \\
\hline Other & 68.4 & (26) & Other & 20.0 & (4) & Other & 15.0 & (3) & Other & 0.0 & (0) \\
\hline TOTAL & 67.5 & (613) & & 21.3 & (193) & & 8.3 & (82) & & 0.4 & (4) \\
\hline
\end{tabular}

"When a teenager commits a crime, which of the following is most responsible, in addition to the teenager? Answer choices: parents, peers, media, and school" (rotated by interviewer).

\section{Method}

Questions concerning parental responsibility were included as part of a larger national Gallup Organization telephone survey conducted in November 1999. Telephone numbers were selected using a random digit dialer. Nine hundred eighty-eight respondents (469 men and 519 women, mean age $=45.6$ years, $\mathrm{SD}=16.5$ ) volunteered to participate in the survey. Three main questions (each of which served as a separate dependent variable) specifically involving parental responsibility were: (1) When a teenager commits a crime, which of the following is most responsible, in addition to the teenager? Response options rotated by the interviewer included: parents, peers, media, and school (responsibility); (2) agreement with this statement: Parents are to blame when their child breaks the law (blame); and (3) agreement with this statement: Parents should be punished when their child breaks the law (punish). For the two agreement questions, the respondents were asked their agreement level on a scale from 1 to 5 with $1=$ strongly disagree, 2 = disagree, 3 = neither agree nor disagree, $4=$ agree, and $5=$ strongly agree. The demographic factors used for this analysis included the respondents' age, race (White, Black, other), education (on an eight-point scale ranging from $1=$ "last grade completed between grades one through four" and $8=$ "beyond college graduate"), yearly income (on an eightpoint scale ranging from $1=$ "less than $\$ 10,000$ " and $8=$ "over $\$ 75,000)$, and political philosophy (on a five-point scale with 1 = "very conservative" and $5=$ "very liberal").

\section{Results}

The first step of the analysis was to assess public opinion of responsibility for a juvenile's crime. General public opinion was examined in addition to opinion as influenced by respondents' demographic characteristics. The second step focused on public support of blaming and punishing parents when their children committed delinquent acts. Once again, respondents' demographic characteristics were highlighted as possible factors that contributed to their level of support.

Table 2

Attitudes toward responsibility by age, political ideology, income, and education

\begin{tabular}{|c|c|c|c|c|c|c|c|c|}
\hline & \multicolumn{2}{|c|}{ Parents } & & \multicolumn{2}{|c|}{ Others } & & \multicolumn{2}{|c|}{ Significance tests } \\
\hline & Mean & $\mathrm{SD}$ & & Mean & $\mathrm{SD}$ & & $\mathrm{T}$ & Sig. \\
\hline Age & 45.90 & 16.70 & Age & 45.11 & 16.17 & Age & -0.73 & 0.46 \\
\hline $\begin{array}{l}\text { Political } \\
\text { ideology }\end{array}$ & 2.76 & 0.90 & $\begin{array}{l}\text { Political } \\
\text { ideology }\end{array}$ & 2.90 & 0.89 & $\begin{array}{l}\text { Political } \\
\text { ideology }\end{array}$ & 2.44 & 0.02 \\
\hline Income & 5.06 & 1.61 & Income & 4.88 & 1.73 & Income & -1.64 & 0.10 \\
\hline Education & 6.79 & 1.68 & Education & 6.69 & 1.62 & Education & -0.90 & 0.37 \\
\hline
\end{tabular}

"When a teenager commits a crime, which of the following is most responsible, in addition to the teenager? Answer choices: parents, peers, media, and school" (rotated by interviewer). 
Table 3

Logistic regression analysis of responsibility as a function of demographic variables

\begin{tabular}{lcccc}
\hline Variables & $\mathrm{B}$ & Wald $X^{2}$ & $p$ & Odds ratio \\
\hline Political ideology & -0.165 & 4.500 & 0.03 & 0.848 \\
Gender & 0.224 & 2.620 & 0.11 & 1.250 \\
Age & 0.002 & 0.161 & 0.69 & 1.002 \\
Income & 0.037 & 0.607 & 0.44 & 1.038 \\
Education & 0.037 & 0.603 & 0.44 & 1.037 \\
Race & 0.158 & 0.639 & 0.42 & 1.170 \\
(Constant) & 0.229 & 0.230 & 0.63 & \\
\hline
\end{tabular}

\section{Responsibility}

Table 1 presents distributions for the responsibility question with respect to race and gender, in addition to the distribution across the full sample. Ninety-six respondents volunteered an answer that was not a designated choice, indicated that all choices provided contributed equally, or refused to answer. Those respondents were excluded from the current analyses (they did not significantly differ along any demographic lines). To restate the question, it asked, "When a teenager commits a crime, which of the following is most responsible, in addition to the teenager?" A majority of respondents designated the parents as the most responsible parties $(68.7 \%)$. Peers came in a distant second at $21.6 \%$. Approximately $9.2 \%$ of respondents put the responsibility on the media. Less than $1 \%(n=4)$ of the respondents placed the responsibility on the schools.

The four original categories were collapsed into two: parents versus others. This was done in an effortto bring the focus more closely on parental responsibility and to decrease the possible influence of unequal sample sizes and the violation of homogeneity of variance. Mean difference comparisons were conducted between these two categories and are presented in Table 2. The only significant difference that appeared between the two groups was based on the respondent's political ideology $(t(964),=2.44, p=0.015)$. On average, respondents who indicated that parents were the most responsible were significantly more conservative than those respondents who indicated some other source of responsibility (Political ideology was on a scale from 1 to 5 with $1=$ very conservative and $5=$ very liberal. Parents: $\mathrm{M}=2.76, \mathrm{SD}=0.895$; others: $\mathrm{M}=2.90$, $\mathrm{SD}=0.887)$. Although this was statistically significant, it might not be practically significant. It should be noted that the means for both groups represented approximately a moderate political ideology (represented by a 3 on the scale).

A binary logistic regression was performed to assess prediction of the responsibility question on the basis of these six demographic characteristics. Once again, the categories of the responsibility question were collapsed to reflect either parents or others as the most responsible. The six demographic predictors were gender, race (White or non-White), age, political ideology, educational attainment, and income. Of the original 988 cases, sixty-five were deleted due to missing data. Missing data appeared to be randomly scattered across the outcome and predictors. Prediction rates were unimpressive with an overall correct prediction rate of approximately $62 \%$. A test of the full model with all six predictors against a constant-only model was not statistically significant, $X^{2}(6, N=923)=11.182, p=$ 0.083 . The variance accounted for was small with a Nagelkerke $R^{2}=0.016$. Table 3 shows logistic regression coefficients, Wald tests, and odds ratios for each of the six predictors. Employing a 0.05 criterion of statistical significance, only political ideology significantly predicted choice of responsibility. Lower scores represented a more conservative viewpoint, thus, the more conservative the respondent, the more likely they were to place responsibility on the parents, holding constant other demographic factors.

Table 4

Attitudes toward blaming and punishing by gender, race, age, political ideology, income, and education

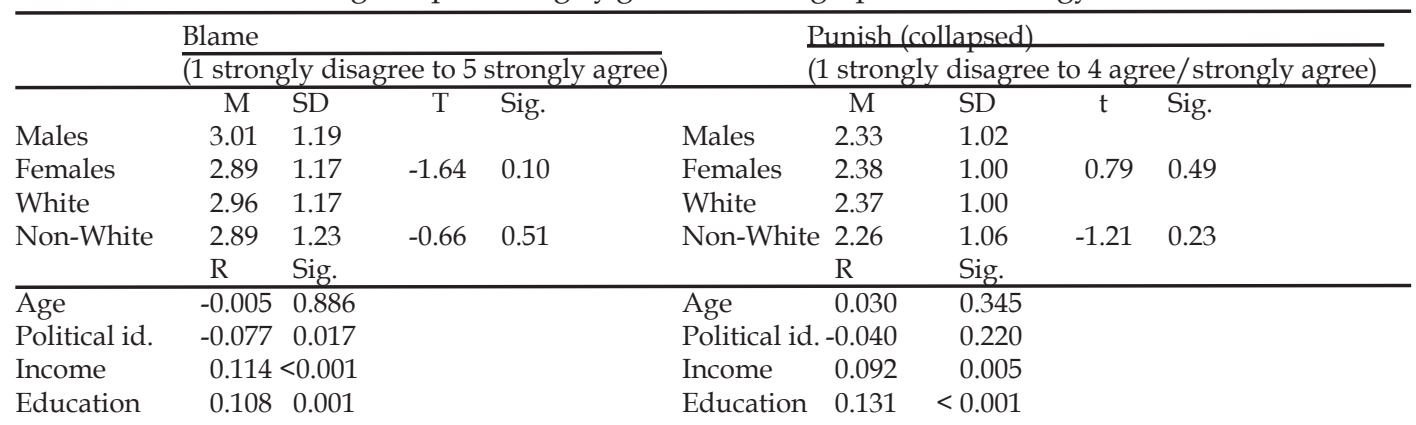


Table 5

Standard multiple regression of demographic variables on agreement level with, "Parents are to blame when their child breaks the law"

\begin{tabular}{|c|c|c|c|c|c|c|c|c|c|}
\hline Variables & Blame (DV) & Gender & Age & Race & Pol. phil & Income & Education & $\mathrm{B}$ & $\beta$ \\
\hline Gender & 0.052 & & & & & & & -0.098 & -0.040 \\
\hline Age & -0.005 & $-0.072 *$ & & & & & & 0.00007 & 0.001 \\
\hline Race & 0.021 & -0.041 & $0.073^{*}$ & & & & & -0.019 & -0.006 \\
\hline Pol. phil. & $-0.077^{*}$ & -0.013 & $-0.150^{*}$ & $-0.066^{*}$ & & & & $-0.100^{*}$ & -0.077 \\
\hline Income & $0.114^{* *}$ & $0.075^{*}$ & $-0.083^{*}$ & $0.134^{*}$ & $-0.067^{*}$ & & & 0.047 & 0.065 \\
\hline Education & $0.108^{* *}$ & 0.011 & $-0.127^{*}$ & 0.023 & 0.056 & $0.464^{* *}$ & & $0.063^{*}$ & 0.089 \\
\hline Means & 2.95 & 0.47 & 45.6 & 0.86 & 2.81 & 5.00 & 6.75 & \multirow{2}{*}{\multicolumn{2}{|c|}{$2.54=$ Intercept }} \\
\hline SD & 1.18 & 0.50 & 16.5 & 0.35 & 0.89 & 1.66 & 1.65 & & \\
\hline & & & & & & & & \multicolumn{2}{|c|}{$\begin{array}{l}R^{2}=0.025 \\
\text { Adjusted } R^{2}=0.019 \\
R=0.154\end{array}$} \\
\hline
\end{tabular}

${ }^{*} p<0.05$.

${ }^{* *} p<0.01$.

Blaming and Punishing

The mean agreement level for the questions concerning whether parents were to blame and whether parents should be punished fell between 2 and 3 (disagree and neither agree nor disagree) (blame $\mathrm{M}=2.95, \mathrm{SD}=1.17$; punish $\mathrm{M}$ $=2.39, \mathrm{SD}=1.07$ ) (see Table 4 ). Pearson's correlation demonstrated a positive linear relationship between the agreement with parents are to blame and parents should be punished when their children break the law, $r(969)=0.529, p$ $<0.001$; however, this correlation was not so strong that the questions appeared to be measuring the same construct. In order to insure a more normal distribution of the response variable by removing outliers, the $3 \%$ of respondents who "strongly agreed" with the statement about punishing parents were collapsed into the "agree" category. The collapsed variable was used in the following analyses.
Table 4 presents the mean comparisons for gender and race with respect to blame and punish. Pearson's correlation coefficients and corresponding significance levels are also presented in Table 4. No significant mean differences were detected between males and females or between Whites and non-Whites. Only education and income resulted in significant correlations with blame and punish. These significant correlations were positive with respondents who had higher educational attainment and higher yearly income also tending to have higher agreement ratings with blaming and punishing the parents.

Using the question related to blaming of parents as the criterion variable and dummy variable coding of the categorical variables, a standard multiple regression was performed. The independent variables included respondents' political ideology, race, age, gender, income, and education. As a result of listwise exclusion,

Table 6

Standard multiple regression of demographic variables on agreement level with, "Parents should be punished when their child breaks the law"

\begin{tabular}{|c|c|c|c|c|c|c|c|c|c|}
\hline Variables & Punish (DV) & Gender & Age & Race & Pol. phil. & Income & Educatior & B & $\beta$ \\
\hline Gender & -0.025 & & & & & & & -0.062 & -0.031 \\
\hline Age & 0.030 & $-0.072 *$ & & & & & & 0.0025 & 0.040 \\
\hline Race & 0.039 & -0.041 & $0.073^{*}$ & & & & & 0.033 & 0.011 \\
\hline Pol. id. & -0.040 & -0.013 & $-0.150^{* *}$ & $-0.066^{*}$ & & & & -0.047 & -0.041 \\
\hline Income & $0.092^{* *}$ & $0.075^{*}$ & $-0.083^{*}$ & $0.134^{* *}$ & $-0.067^{*}$ & & & 0.015 & 0.024 \\
\hline Education & $0.131^{*}$ & 0.011 & $-0.127^{* *}$ & 0.023 & 0.056 & $0.464^{* *}$ & & $0.082^{*}$ & 0.132 \\
\hline Means & 2.36 & 0.47 & 45.6 & 0.86 & 2.81 & 5.00 & 6.75 & $1.75=$ Int & ept \\
\hline SD & 1.01 & 0.50 & 16.5 & 0.35 & 0.89 & 1.66 & 1.65 & & \\
\hline \multicolumn{10}{|c|}{$\begin{array}{l}R^{2}=0.024 \\
\text { Adjusted } R^{2}=0.018 \\
R=0.155\end{array}$} \\
\hline
\end{tabular}


916 respondents were included in the regression. Table 5 includes the correlations between the variables, the unstandardized regression coefficients (B), the intercept, the standardized regression coefficients $(\beta), R^{2}$, and adjusted $R^{2} . R$ for regression was significantly different from 0 , $F(8,909)=3.91, p=0.001$. The two regression coefficients that differed significantly from 0 , were political ideology and education. These regression coefficients indicated that the more conservative a respondent was, the higher agreement rating they had with blaming of the parents. The higher the level of education, the higher the agreement rating with blaming parents. Overall, the prediction was unimpressive with $2.5 \%$ (1.9\% adjusted) of the variability in blaming predicted by knowing the scores on these six demographic independent variables.

A second multiple regression was performed using the question related to punishing of parents (collapsed version with four-point scale) as the criterion variable with the same independent variables as was used in the model for blaming parents. As a result of listwise exclusion, 905 respondents were included in the regression. Table 6 includes the correlations between the variables, the unstandardized regression coefficients $(B)$, the intercept, the standardized regression coefficients $(\beta), R^{2}$, and adjusted $R^{2} . R$ for regression was significantly different from 0 , $F(6,904)=3.721, p=0.001$. Only education's regression coefficient differed significantly from 0 . Prediction was again unimpressive and slightly lower than it was for the blaming model with $2.4 \%$ ( $1.8 \%$ adjusted) of the variability in punishing predicted by knowing the scores on these six demographic independent variables.

\section{Discussion}

A false perception of increased teen violence led politicians and the media to call for a more punitive juvenile justice system. The original rehabilitation objective of the juvenile system gave way to punishing juveniles the same way adults were punished (Ainsworth, 1991; Feld, 1991; Heilbrun et al., 1997). In contrast to these two movements toward greater juvenile accountability, a simultaneous movement was taking place that imposed legal responsibility on parents for their children's actions. Research demonstrated that the public supported the "get tough" on juvenile crime attitude (Gallup Poll Surveys, 2000) that was often characterized by trying juveniles in the adult criminal system. It was not known if a similar attitude would be present toward the parents. The present study examined this possibility intending to explore the extent to which demographic variables related to different aspects of beliefs about parental responsibility.

As predicted, the public clearly placed some responsibility on parents when juvenile crime occurred. A vast majority of the respondents to this survey indicated that, after the juvenile, the parents were the most responsible for a juvenile's crimes. Overall agreement with blaming and punishing the parents, however, was lower than expected. This seemingly incongruent finding was best explained by viewing the three parental questions as graduated from least severe to most severe. Indicating that parents were the most responsible, after the juvenile, was the least severe expression of condemnation toward parents. The next severe was blaming the parents. Punishing the parents when their children committed illegal acts was the most severe.

This finding might be explained in two different ways. First, respondents might have viewed parents as morally responsible for the actions of their children, but still did not believe that the government should impose punishments. Parents might be viewed as the ultimate guardians of their children's well being; however, imposing a legal punishment appeared to make the state involvement too harsh and took the notion of moral responsibility too far. The second explanation for higher blaming/responsibility than punishing might be an issue of question wording. Participants might have only been thinking of traditional criminal punishments, such as imprisonment and fines, when asked about punishing parents. It might be that people would be more agreeable with other forms of parental responsibility, if given the option.

For agreement with blaming and punishing the parents, demographic variables were only partially helpful in predicting who placed blame and who wanted to punish the parents. In support of the hypotheses, those respondents who had lower incomes and less education were less likely to agree that parents should be blamed or punished when their children committed delinquent acts. These findings corresponded with those by Blumstein and Cohen (1980) who reported greater punitiveness for those from higher income brackets. In contrast to Banks et al. (1975), no age differences were found in this survey using age as a continuous variable. This dif- 
ference might be attributed to the twenty-fiveyear time span between the Banks et al. study and the current survey. During these twentyfive years, people continued to have children later in life, therefore increasing the likelihood that older respondents would have young children still living at home.

Results from the two multiple regressions suggested that the demographic variables as a set did not account for much of the variability in the agreement levels with blaming or punishing parents. Neither race nor gender was a significant predictor. The findings indicated that across the different genders and races, respondents viewed punishment the same. Respondents might have believed that parents should be blamed more than they thought parents should be punished, but both agreement ratings were fairly weak. Both mean ratings were near the mid-range of the scale, indicating that participants disagreed that parents should be held responsible or punished for their children's crimes. The great majority of agreement ratings were in the low to middle range (disagree or neither agree or disagree) indicating that people did not have strong opinions on this issue. This lack of opinion strength might have contributed to the inability to accurately predict opinions using demographic characteristics. Past research found that attitudes must be salient in order for them to be predictive of behavior (Ajzen \& Fishbein, 1977). People were relatively non-committal on the issue; thus, it made it more difficult to predict their opinions.

A clear limitation of this research was the measurement of global rather than specific attitudes. General polls might not be able to provide detailed information because they were difficult to interpret with any consistent precision (Roberts, 1996). For instance, the public greatly endorsed recidivist statutes (i.e., "Three Strikes and You're Out" laws) when asked about broad, single-item questions concerning these laws $(88.4 \%$ either strongly supported or somewhat supported these laws). This endorsement was greatly reduced when the respondents were presented with specific situations that would be covered pursuant to these laws (Applegate et al., 1996). In the current research, this issue might be most prominent in thinking about the effect of the juvenile's age/competency level and the type of delinquent act. In other words, was there a positive or negative correlation between the age at which the juvenile committed a delinquent act and the public's support of blaming and punishing that child's parents? Additionally, was there a positive or negative correlation between the severity of the juvenile's offense and the public's support of blaming and punishing that child's parents? Both of these questions could be answered in future research by employing methods similar to those used in the three-strikes area by Applegate and his colleagues.

Future research should extend the three main dependent variables used here. A more in-depth measurement scheme could be employed to measure these constructs more thoroughly. For instance, scale construction could be utilized to determine public support of punishment by focusing on different types of punishment and for different types of delinquent acts. Research could also focus on the public's understanding of a delinquent family's needs and circumstances. Does the public understand the complex interactions and influences that affect a family? For instance, Bronfenbrenner (1979) suggested an ecological approach for studying human development in which children were not just within the family environment, but also within a series of "nested" environments. These additional environments included the parents' workplace, national influences, among other influences that vastly shaped the family and the way the child developed. Would a consideration of extra-familial influences change public opinion?

Additional respondent characteristics should be investigated. One possible direction would entail investigating a self-interest component to these attitudes. Self-interest, operationalized using parental status, was shown to influence similar attitudes (Crowe \& Bailey, 1995). Parents might be even less likely to support these constructs because of their own self-interest in the area. It follows that a parent with a delinquent child would also be even less likely to support parental responsibility because of a more salient self-interest.

\section{Conclusion}

This research presented an investigation of public opinion in the relatively new area of parental responsibility. With the imposition of the varying forms of these laws, it is important to first understand if the public has a general support of such laws, and second, to understand the underlying reasons for such support. Overall, support for the concepts underlying these 
laws (responsibility, blame, and punishment) was relatively mixed. In general terms, the public appeared willing to place some responsibility on parents, but less willing to support blaming or punishing the parents. Most notable, these opinions were fairly consistent across the normal demographic lines that influenced attitudes on other issues. Respondents' race, gender, and age made no difference in their opinions regarding the underlying concepts of parental responsibility laws. This research suggested that recent state legislative trends in imposing legal consequences, particularly punishment, on parents for their children's actions might not hold wide public support. Further research is recommended to determine whether there is public support for holding parents responsible in ways other than punishing them.

\section{Acknowledgements}

This research was partially completed as a component of the first author's dissertation under the faculty direction of Victoria Weisz, Ph.D., MLS, from the University of Nebraska, Lincoln, Center on Children, Families, and the Law. It was presented at the 2002 meeting of the American Psychology and Law Society in Austin, Texas. This research was financially supported in part by the National Institute of Mental Health Training Grant (5 T32 MH16156), an American Psychology and Law Society Grants-in-Aid, and a Warden grant from the Department of Psychology at the University of Nebraska. The authors wish to acknowledge Steven Penrod and Alex Piquero for their comments and suggestions on earlier drafts. The Gallup Organization agreed to complete the data collection for this research as part of an agreement with the University of Nebraska's Survey Design course instructor, Dr. Allan McCutcheon.

\section{References}

Ainsworth, J.E. (1991). Re-imagining childhood and reconstructing the legal order: the case for abolishing the juvenile court. North Carolina Law Review 69: 1,083-1,109.

Ajzen, I., and M. Fishbein (1977). Attitude-behavior relations: a theoretical analysis and review of empirical research. Psychological Bulletin 84: 888-912.

Applebome, P. (1996, June 16). A carrot and stick for parenthood. New York Times, p. E5.

Applegate, B.K., F.T. Cullen, M.G. Turner and J.L. Sundt (1996). Assessing public support for threestrikes and you're out laws: global vs. specific attitudes. Crime and Delinquency 42: 517-534.

Banks, C., E. Maloney and H.D. Willcock (1975). Public attitudes to crime and the penal system. British Journal of Criminology 15: 228-240.
Bartollas, C., and S.J. Miller (1994). Juvenile Justice in America. Englewood Cliffs, N.J.: Regents/Prentice Hall.

Bilchik, S. (2000, February). Challenging the Myths. Office of Juvenile Justice and Delinquency Prevention, 1999 National Report Series (NCJ 178993). Washington, D.C.: U.S. Department of Justice.

Bishop, D.M., and C.E. Frazier (1991). Transfer of juveniles to criminal court: a case study and analysis of prosecutorial waiver. Notre Dame Journal of Law, Ethics and Public Policy 5: 281-302.

Blumstein, A., and J. Cohen (1980). Sentencing of convicted offenders: an analysis of the public's view. Laws and Society Review 14: 223-261.

Bouley, E.E., and T.L. Wells (2001). Attitudes of citizens in a southern rural county toward juvenile crime and justice issues. Journal of Contemporary Criminal Justice 17: 60-70.

Brank, E.M., S.C. Kucera and S.A. Hays (2003). Parental Responsibility Statutes: An Organization and Policy Implications. Manuscript in preparation.

Bronfenbrenner, U. (1979). The Ecology of Human Development: Experiments by Nature and Design. Cambridge, Mass.: Harvard University Press.

Crowe, J.W., and W.J. Bailey (1995). Self-interest and attitudes about legislation controlling alcohol. Psychological Reports, 76: 995-1,003.

Davies, H.J., and H.A. Davidson (2001). Parental Involvement Practices of Juvenile Courts. Washington, D.C.: American Bar Association.

DiFonzo, J.H. (2001). Parental responsibility for juvenile crime. Oregon Law Review 80: 1-107.

Ellsworth, P.C., and S.R. Gross (1994). Hardening of the attitudes: Americans' views on the death penalty. Journal of Social Issues 50(2): 19-52.

Feld, B.C. (1991). The transformation of the juvenile court. Minnesota Law Review 75: 691-725.

Furnham, A., and M. Henderson (1983). Law theories of delinquency. European Journal of Social Psychology 13: $107-120$.

Gallup Poll Surveys. (2000, August 29 to September 5). Gallup poll social series: Crime. Retrieved from: http:/ / www.gallup.com/poll/surveys / 2000/ topline000829/topline000829.asp.

Gardner, M.R. (1997). Understanding Juvenile Law. New York: Matthew Bender.

Gottfredson, M.R., and T. Hirschi (1990). A General Theory of Crime. Stanford, Calif.: Stanford University Press.

Hanson, R.K. (1989a). Parental liability. Wisconsin Lawyer 62: 24-28.

Hanson, R.K. (1989b). The parental liability issue in Oregon. Children's Legal Rights Journal 1: 7-12.

Heilbrun, K., C. Leheny, L. Thomas and D. Honeycutt (1997). A national survey of U.S. statutes on juvenile transfer: implications for policy and practice. Behavioral Sciences and the Law 15: 125-149.

Hine, T. (1999). The Rise and Fall of the American Teenager. New York: Avon Books. 
Hirschi, T., and M. Gottfredson (1993). Rethinking the juvenile justice system. Crime and Delinquency 39: 262-272.

Hollin, C.R., and K. Howells (1987). Lay explanations of delinquency: global or offense-specific? British Journal of Social Psychology 26: 203-210.

Kenny, J.A., and J.V. Kenny (1961). Shall we punish the parents? American Bar Association Journal 47: 804808.

Kingdon, J.W. (1995). Agendas, Alternatives, and Public Policies (2nd ed.). New York: Harper Collins College Publishers.

Levine, R.C. (1984). Parental liability for the torts of their minor children: limits, logic, and legality. Nova Law Journal 9: 205-229.

Lock, E.D., J.M. Timberlake and K.A. Rasinski (2002). Battle fatigue: is public support waning for 'war'centered drug control strategies? Crime and Delinquency 48: 380-398.

Moffitt, T.E. (1993). Adolescence-limited and lifecourse persistent antisocial behavior: a developmental taxonomy. Psychological Review 100: 674-701.

Moon, M.M., J.P. Wright, F.T. Cullen and J.A. Pealer (2000). Putting kids to death: specifying public support for juvenile capital punishment. Justice Quarterly 17: 663-684.

Patterson, G.R., B.D. DeBaryshe and E. Ramsey (1989). A developmental perspective on antisocial behavior. American Psychologist 44: 329-335.

Podkopacz, M.R., and B.C. Feld (2001). The back-door to prison: waiver reform, "blended sentencing," and the law of unintended consequences. Journal of Criminal Law and Criminology 91: 997-1,071.

Quinn, K.M. (2002). Juveniles on trial. Child and Adolescent Psychiatric Clinics of North America 11: 719-730.

Radelet, M.L., and M.J. Borg (2000). The changing nature of death penalty debates. Annual Review of Sociology 26: 43-61.

Reuterman, N. (1978). The public's view of delinquency causation: a consideration in comprehensive juvenile justice planning. Juvenile and Family Court Journal 29: 39-47.
Roberts, J.V. (1996). Public opinion, criminal record, and the sentencing process. American Behavioral Scientist 39: 488-499.

Samborn, H.V. (1996). Kids' crimes can send parents to jail. American Bar Association Journal 82: 28-30.

Schiraldi, V., and J. Ziedenberg (2001). How distorted coverage of juvenile crime affects public policy. In: W. Ayers, B. Dohrn and R. Ayers (editors), Zero Tolerance: Resisting the Drive for Punishment in Our Schools (pp. 114-125). New York: New Press.

Snyder, H.N. (2000, December). Juvenile arrests 1999. Office of Juvenile Justice and Delinquency Prevention, Juvenile Justice Bulletin.

Tyler, T.R. (1990). Why People Obey the Law. New Haven, Conn.: Yale University Press.

Tyler, T.R., and R.J. Boeckmann (1997). Three strikes and you are out, but why? The psychology of public support for punishing rule breakers. Law and Society Review 31(2): 237-267.

Warr, M., R.F. Meier and M.L. Erickson (1983). Norms, theories of punishment, and publicly preferred penalties for crimes. Sociological Quarterly 24: 75-91.

Weitzer, R., and S.A. Tuch (2002). Perceptions of racial profiling: race, class, and personal experience. Criminology 40: 435-456.

White, H.G., C.E. Frazier and L. Lanza-Kaduce (1999). A socio-legal history of Florida's juvenile transfer reforms. University of Florida Journal of Law and Public Policy 10: 249-275.

Cases Cited

Breed v. Jones, 421 U.S. 519 (1975).

In re Gault, 387 U.S. 1 (1967).

In re Winship, 397 U.S. 358 (1970).

Kent v. United States, 383 U.S. 541 (1966).

McKeiver v. Pennsylvania, 403 U.S. 528 (1971).

Statute Cited

Intent-Purpose (1997). Wash. Rev. Code Ann. § 13.40.010. 